\title{
Assessing the effect of climate change and
} financial development on agricultural production in ASEAN-4: The role of renewable energy, institutional
quality and human capital as moderators

Abbas Ali Chandio ( $\square$ alichandio@sicau.edu.cn )

Sichuan Agricultural University - Chengdu Campus https://orcid.org/0000-0001-8706-9681

Muhammad Ibrahim Shah

BRAC University

Narayan Sethi

National Institute of Technology Rourkela

Zulqarnain Mushtaq

Xi'an Jiaotong University

\section{Research Article}

Keywords: ASEAN-4, Agriculture, Climate Change, Renewable, Human capital, Institutional quality

Posted Date: August 17th, 2021

DOl: https://doi.org/10.21203/rs.3.rs-760373/v1

License: (c) (i) This work is licensed under a Creative Commons Attribution 4.0 International License.

Read Full License

Version of Record: A version of this preprint was published at Environmental Science and Pollution Research on September 28th, 2021. See the published version at https://doi.org/10.1007/s11356-02116670-9. 


\title{
Assessing the effect of climate change and financial development on agricultural production in ASEAN-4: The role of renewable energy, institutional quality and human capital as moderators
}

\author{
Abbas Ali Chandioa* \\ ${ }^{a}$ College of Economics, Sichuan Agricultural University, Chengdu 611130, China \\ Email:alichandio@sicau.edu.cn \\ Muhammad Ibrahim Shah ${ }^{b}$ \\ ${ }^{\mathrm{b}}$ BRAC Institute of Governance and Development, BRAC University, Dhaka, Bangladesh \\ Email: ibrahimecondu@gmail.com
}

\author{
Narayan Sethic \\ 'Department of Humanities and Social Sciences, National Institute of Technology Rourkela, \\ Rourkela, Odisha 769008, India \\ Email: sethin@nitrkl.ac.in

\section{Zulqarnain Mushtaq ${ }^{\mathrm{d}}$} \\ ${ }^{\mathrm{d}}$ School of Economics and Finance, Xian Jiaotong University, China \\ Zulqarnainmushtaq@yahoo.com
}

*Corresponding author: Email addresses: alichandio@sicau.edu.cn (A. A. Chandio)

\section{Abstract}

This study utilizes the data of ASEAN-4 nations, namely Indonesia, Malaysia, Philippines, and Thailand, to examine how climate change, renewable energy, human capital, institutional quality as well as financial development affect the agricultural production. Since shocks in one country can easily affect another country of this region, the second generation modelling techniques are utilized to prove the relationship among the variables of interest. Findings from the Westerlund (2007) cointegration test confirms long run relationship among the variables. The result from Cross-sectionally augmented autoregressive distributed lag (CS-ARDL) model reveals that climate change negatively affects the agricultural production, renewable energy, human capital, institutional quality positively affects the agricultural production. Moreover, renewable energy use, human capital and intuitional quality moderates the effect of carbon emission on agricultural production. In addition, a $U$ shaped relationship between financial 
development and agricultural production is discovered, suggesting that financial development can promote production in the agricultural sector only after reaching a certain threshold. Finally, some policy recommendations are provided for the ASEAN-4 countries.

Keywords: ASEAN-4, Agriculture, Climate Change, Renewable, Human capital, Institutional quality

\section{Introduction}

Contemporary climatic conditions, caused by the increasing concentration of greenhouse gases, are posing a grave threat to human life and biodiversity. This is particularly true for the agricultural sector since the increase in average annual temperature and other climatic changes are deteriorating the productivity growth of this sector and aggravating global food insecurities (Abbas, 2020; IPCC, 2014; Kotir, 2011). Many species of agricultural crops are highly sensitive to climatic changes associated with increasing temperature, changing pattern and intensity of rainfall, concentration of carbon dioxide $\left(\mathrm{CO}_{2}\right)$, rising sea level, and intensity of natural disasters (Ahmad et al., 2020; Boonwichai et al., 2019; Mendelsohn, 2014). Productivity growth of major food crops such as wheat, rice, cereals, fruits, vegetables, meat, and date production, besides others, is dependent on favourable climatic conditions (Zaied and Cheikh, 2015). Furthermore, climate-induced shocks and stresses are a major obstacle in reducing poverty and food insecurities as worsening of climatic events have become a severe problem to the sustainability of countries where the agriculture sector plays a crucial role in improving livelihood and food security. Climate change is severely affecting the livelihoods of the rural population that occupy about $40 \%$ of land and consume more than $70 \%$ of water resources globally (Masters et al., 2010). In particular, developing countries in Africa and Asia are highly vulnerable to food insecurities due to extreme climatic events (Aryal et al., 2019). 
decades due to the restructuring of their economies and policies in the early 1980s. They transformed their economic profile from producer and exporter of primary agriculture products to exporter of processed agricultural products and manufactured goods. Despite the successful manufacturing sector development during the last decades, the agriculture sector remains one of the important sectors for ASEAN-4, which ensures food availability for the increasing population. The total area of agricultural land of ASEAN-4 countries in 2018-19 was 33.2 percent, 26.1 percent, 41.7 percent, and 43.3 percent of total land area respectively in Indonesia, Malaysia, Philippines, and Thailand. These agricultural lands have employed 28.49 percent of total employment in Indonesia, 10.28 percent in Malaysia, 22.86 percent in the Philippines, and 31.43 percent in Thailand during 2019, (WDI, 2021). The agriculture sector plays a crucial role in economic growth, employment, food security, and rural poverty elevation in the ASEAN-4 countries.

However, the South East Asian region is one of the most vulnerable regions in terms of climatic extremes such as an increase in heat extremes, rising sea level, increasing intensity of tropical cyclones, ocean warming, and acidification. The most important climate threat to this region is sea-level rising which is expected to be 10 percent higher than the global average (Bank, 2013). If climate change is not addressed, ASEAN-4 can suffer loss equivalent to 6.7 percent of GDP annually by 2100 and more than 13 million people can fall into extreme poverty by 2030 due to decreasing crop yield (Bank, 2013). Indonesia and the Philippines could face the depth of food insecurity and poverty due to climatic extremes. Among ASEAN-4, the global climate risk index ranked the Philippines the second most affected country in 2018, and the Philippines and Thailand among the top ten highly affected countries in the world from 1999 to 2018, (Eckstein et al., 2019). According to the IPCC (2014) report revealed that this region will suffer more extreme climatic events and food crisis in future decades. It is, 
therefore, necessary for ASEAN-4 countries to tackle climate change in an effective manner (Mahmoud et al., 2019).

Fossil fuel consumption in agriculture and other sectors is one of the major sources of GHGs emission, and the global food system is responsible for 19 percent and 29 percent of GHS emission directly and indirectly, (Vermeulen et al., 2012). Amid rapid economic growth, South East Asian nations are witnessing a large increase in regional demand for energy. To mitigate GHGs emissions associated with fossil fuel consumption, the ASEAN nations are adopting renewable technology to generate clean energy. According to International Renewable Energy Agency (IRENA, 2016), this region intends to generate 23 percent of primary energy and 35 percent of installed power from renewable sources by 2025 . ASEAN-4 nations are witnessing remarkable investment in renewable energy in the region. Approximately 50 percent of installed regional renewable energy is generated by Thailand (17 percent), Indonesia (13 percent), Malaysia (10 percent), and the Philippines (10 percent), (IRENA, 2016). This region has vast potential to generate renewable energy from solar, thermal, hydro, tidal, wave generated power, and biomass. The increasing investment in renewable energy generation can address environmental concerns and increase long term clean food supply.

The theory has identified numerous factors significantly affecting agricultural production, for example skilled human capital, industrialisation, and financial development as well as institutional quality (Zakaria et al., 2019). The increasing urge and adoption of clean production activities across ASEAN nations have increased the demand for skilled human capital in agriculture and other sectors. Schumpeter (1982) in his theory of economic development argued for human capital development for invention and innovation that are required for sustainable economic prosperity. It implies that sustainable regional development lies in the enhancement and expansion of human capital development through increasing 
regional investment in health, nutrition, education, knowledge, skills, and capacity building.

The ASEAN nations are facing a wide disparity in their human capital development and economic growth prospects. The World Intellectual Property Organization has witnessed considerable heterogeneities among ASEAN nations in terms of the global innovative index (GII). Among ASEAN-4 countries, Malaysia ranked 33rd position in GII, which is followed by Thailand (44th position), Philippines (50th position), and Indonesia (85th position), (GII, 2020). In order to reduce regional disparities in human capital development a high-level meeting of ASEAN nations held on 9 September 2019 in Bangkok that has urged for the enhancement in regional cooperation for sustainable human capital development. Besides human capital, improvements in the quality of institutions can play an important role in the enhancement of agriculture sectors' productivity. The quality of institutions can be measured by the prevalence of corrupt practices. The farmers are exposed to various types of corruption particularly on getting subsidies on irrigation, fertilizer market, agriculture pricing, seed market, storage, and transportation, (Anik and Bauer, 2017). Quah (1982) noted that bureaucratic corruption is one of the most serious and embarrassing obstacles to the national technologies and invest in farming sector, which greatly helps to boost agricultural productivity and improve livelihood of the farmers. It provides financial facilities to farmers to purchase modern inputs such as high yields varieties, agrochemicals, and fertilisers as well as machinery, 
easy accessible financial services are essential to increase per worker agricultural productivity (Anh et al., 2020). Agricultural financing can be provided by the public sector via the banks and other formal credit institutions. Thus, agricultural policies mainly focus on easy access to agricultural credit to increase farm productivity and improve the livelihoods of the farmers, particularly the smallholder farmers in rural economies (Elahi et al., 2018).

Owing to the above discussion, this study makes several contributions to the empirical literatures. First, numerous studies have found different impacts of climate change on agricultural production depending on the geographical location or the types of crops cultivation in that region (Verchot et al., 2007). These have reported mixed result (Janjua et al. (2014); Qureshi et al. (2016); Ali et al., (2017); and Chandio et al. (2020a). In ASEAN-4 region, few empirical studies have been documented to investigate the climate change impacts on crops production, adaptation strategies, and current trends. These empirical studies have been conducted for individual countries, i.e. Malaysia (Harun et al., 2021; Sarkar et al., 2020), Indonesia (Panuju et al., 2013; Takahashi and Barrett, 2014), and Thailand (Boonwichai et al., 2019; Chiarawipa and SDOODEE, 2020). However, our study focuses on all these 4 countries to see whether climate change causes any disruption in their agricultural production. Second, this study considers several measures that can be adopted to tackle the impacts of climate changes on agricultural production. These measures come in the form of level effect and moreover in the form of interaction effects such as interaction between $\mathrm{CO}_{2}$ and renewable use, $\mathrm{CO}_{2}$ and quality of government and $\mathrm{CO}_{2}$ and human capital development. Third, since the measures taken in one country can easily affect another country of ASEAN-4 region, it is necessary to conduct panel estimation using cross sectional dependence. In our study, we use second generation estimation techniques such as cross sectional Chudik and Pesaran (2015) Cross-Sectional Dependence test, Second-Generation Panel Unit Root test such as CIPS and CADF, Westerlund (2007) cointegration test, long run estimation techniques such as CS- 
ARDL. The results of CS-ARDL is again validated by other novel estimation techniques which can also tackle cross sectional dependence test such as CS-DL and CCE.

Rest of the paper is organized as follows: section 2 deliberates the reviewed empirical literature, section 3 discusses methodological framework, section 4 analyses the estimated results obtained from the econometric investigation, and section 5 concludes the study with policy recommendations.

\section{Literature review}

\subsection{Climate change and agriculture}

Agriculture is a primary sector of Asian developing countries that provides food, income, and several main inputs along with the climatic changes interlinked with rising temperatures, changing patterns of rainfall, and floods. This section reviews some previous studies on the impacts of climate change on agricultural production in different regions of the world.

The pioneering work on climate change and agricultural production in Pakistan from 1984-2017 has been conducted by Ahmad et al., (2020). Findings of ARDL model has revealed that increasing annual average temperature and $\mathrm{CO}_{2}$ emission negatively and significantly affected the agricultural production in the short-term (SHT) and long-term (LT). Similarly, Warsame et al. (2021) used the temperature and $\mathrm{CO}_{2} \mathrm{e}$ and rainfall as a proxy for climate change and found that temperature and $\mathrm{CO}_{2}$ e negatively declined the crop production, whereas rainfall and cropped area significantly contributed in the long-term in the case of Somalia. Further, the research done by Pickson et al., (2020) explored the nexus of climate change and cereal production for China for 1990Q1-2013Q4 using the ARDL, Johansson cointegration, and Granger causality test have found that $\mathrm{CO}_{2} \mathrm{e}$ and average temperature severely affected cereal production, whereas average rainfall, cultivated area, and agricultural worker significantly enhanced cereal production in both short-term and long-term. 
effects on agricultural sector in Bangladesh. The net crop income in the country was seen to the yield of major crops in Bangladesh due to varying temperature, humidity and rainfall. Tirado and Cotter (2010) and Praveen and Sharma (2019) state that a change in the rainfall pattern leads to water scarcity and drought for crops and modifications in irrigation facilities.

Consequently, the change in the temperature and moisture levels alters the yield output due to the altered absorption rate of fertilisers and minerals. Further, Guntukula (2020) studies 58 years (1961-2017) of data on variations of yields of food and non-food crops in India due to climate change to find that an increase in rainfall levels adversely affects the food crops save pulses, and positively affects the yields of non-food crops in the country. Increase in temperature is also seen to positively affect the production of crops except rice. The results of an econometric analysis of the impact of climate change on soybean yield in Iran by Yuzbashkandi and Khalilian (2020) reveal that, rising temperature and precipitation are beneficial for soybean production. Moreover, the study suggests that the effect of different parameters of climate change may vary according in scale. Furthermore, the study by Chandio et al. (2020c) suggest that $\mathrm{CO}_{2}$ emissions have a positive effect on rice production in Pakistan both in the long- and short-run. Similarly, Rayamajhee et al.(2020) show that a rise in precipitation levels negatively affects rice production in Nepal.

\subsection{Renewable energy and agriculture}

The agriculture sector is a major consumer of fossil energy that is responsible for environmental degradation and global warming. The fossil fuel consumption in the production process made the agriculture system an important source of greenhouse gases (GHGs) emission. According to Vermeulen et al. (2012), the agricultural system is responsible for 19 
percent direct and 29 percent indirect GHGs emissions. The use of renewable energy for agricultural activities can have many economic and environmental advantages for farmers. There are many sources of renewable energy such as solar, hydropower, wind, tidal, thermal, and biomass. The emergence of environmental concern across the globe and carbon taxation has made renewable energy as best alternatives for sustainable development of the agriculture sector.

The plethora of empirical literature stressed the importance of renewable energy on et al., 2021). However, literature on the effect of renewable energy consumption and the performance of the agriculture sector is scant. Among them, Jebli and Youssef (2015) investigated the short run and the long-run relationship between carbon dioxide $\left(\mathrm{CO}_{2}\right)$ emissions, gross domestic product, renewable energy, and non-renewable energy and agricultural value-added in Tunisia from 1980 to 2011 by using co-integration, vector error correction model (VCEM), and Granger causality test. The objective was to explore causal relationships between renewable energy and agriculture and to evaluate its impact on $\mathrm{CO}_{2}$ emissions. The estimated result reveals the causal relationship between renewable energy and agriculture value addition; whereas, in the long-run renewable energy consumption reduces $\mathrm{CO}_{2}$ emission. The study urges the use of renewable energy at a national level to make the agriculture sector environmentally friendly. Fami et al. (2010) investigated reasons for using non-renewable energy in Iran by surveying 2400 small farmers and collected a sample of 133 people by using Cochran formula and random sampling techniques. The finding has revealed that the majority of respondents are using non-renewable energy and methods due to lack of advance renewable technologies. The major reasons for fossil energy use in many activities are ease of access and lower cost. This study urges the government to encourage the adoption of renewable energy technologies to abandon fossil fuel. 

generation of renewable energy from wind, thermal, tidal, biomass, and other sources. The increasing adoption of renewable energy can affect the performance of both the agriculture and manufacturing sector. The review of the literature does not found any study that explores how the use of renewable energy can impact the performance of the agriculture sector.

\subsection{Institutional quality and agriculture}

244 North (1990) has defined institutions as humanly devised constraints that explain economic, political, and social interaction. These institutions have been developed to create order and reduce uncertainties. Institutional quality plays a crucial role in process of economic growth and development by creating order and reducing uncertainties. Fisman and Svensson (2007) investigated the relationship between bribe payments and taxes on firm-level growth in Uganda by using firm-level data from 1995 to 1997 . The finding has revealed that both taxation and bribes negatively influence firm growth, but the impact of corruption is much higher than agricultural taxation. They concluded that the negative impact of corruption is three times greater than taxation.

The structure of the agricultural sector is a complex socio-economic system containing economic, organiza-tional, legal, moral, and ethical elements. The quality of institutions thus plays an important role in the achievement of sustainable agricultural development. The review of empirical studies also stressed the importance of institutional quality. Ahmed et al., (2010) investigate the relationship between institutional quality and productivity growth in the agriculture sector of transition countries of Eastern Europe from 1996 to 2015 by using a dynamic panel model on the neoclassical growth framework. The findings reveal that poor quality on institutions distorts agriculture productivity and growth. The major institutional factor responsible for the deterioration in productivity growth is the high degree of corruption prevalent in selected countries. However, privatization and transferability of land have a 
sluggish positive impact on the productivity growth of the agriculture sector. This study urges for improvement in institutional quality to accelerate productivity growth. Whereas, Anik et al. (2011) examined the effect of corruption cost on firm-level efficiency of rice production in Bangladesh during 2018-19 by using a survey of 210 rice producers. The data has been analyzed by using a stochastic frontier model, and estimated results reveal that on average corruption cost have both positive and negative impact on farmers of rice production. If farmer able to acquire more agricultural inputs through bribes, then it enhances technical efficiency of the farmers, negative otherwise.

In recent studies, Drebee and Abdul-Razak (2020) explored the short-run and long-run impact of corruption on agriculture sector growth in Iraq by using quarterly data from 2004Q2 - 2019Q4 by using the Johansen and Juselius cointegration, and the VECM model. The finding of cointegration analysis shows the existence of a long-run equilibrium relationship between corruption and productivity growth of the agriculture sector. The estimated result found that corruption is distorting the productivity of the agriculture sector in Iraq and urges for policies that combat corruption to improve performance. Subramaniam et al. (2020) explored the impact of institutional quality on food supply in 56 developing countries by employing dynamic generalized methods of moments on panel data. The estimated results have revealed that the quality of institutions plays a vital role in improving food availability and access to required nutrition. The study urges policymakers to improve institutional quality to alleviate hunger and food security.

\subsection{Human capital and agriculture}

The classical economic development theory of Schumpeter (1982) stressed the importance of human capital for sustainable economic and agriculture sector development. Innovation in production technology is possible through human capital development. The neoclassical economist considers human capital as major determinants and argues for investment in 
education, and other training programs for enhancement, (Schultz, 1961). The agriculture sector of this century is facing unprecedented pressure due to the reduction in agricultural land and extreme climatic events. The sustainable development of agriculture technology is a major challenge, which is only possible through education and human capital development, (Hayami and Ruttan, 1970). The plethora of empirical literature has found a significant positive impact of human capital development on the agriculture sector productivity. Sabir and Ahmed (2008)evaluated the impact of economic reforms on total factor productivity of Pakistan and its three major sectors such as agriculture, manufacturing, and services sector from 1972-73 to 2001-2002. The findings show that the total factor productivity of the agriculture sector is determined by the human capital development and subsidies on cotton. Moreover, the elasticity coefficient of human capital development is the highest. Whereas, subsidies on food have negligible impact, and fertilizer subsidies reveal negative impact. This study urges Pakistan to invest in human capital development to enhance total factor productivity in all sectors.

The impact of human capital development on agriculture sector productivity and income of farmers in Cameron has been investigated by Djomo and Sikod (2012). They have employed a stochastic frontier model on household-level data that is collected from the National Institute of Statistics. The findings reveal that increase in human capital through additional experience and education level is enhancing agriculture sector productivity and urges the government to facilitate farmers to endow more human capital. Similarly, Ahmad and Heng (2012) investigated determinants of agriculture sector productivity in Pakistan by employing the ARDL model from 1965 to 2009. The estimated results have revealed that after fertilizer consumption, the most important determinant of agriculture sector productivity is human capital with elasticities 0.16 and 0.20 in the short-run and long-run, respectively. This study urges for improvement in human capital along with other inputs to enhance the productive performance of the agriculture sector. 

productivity of human capital and education on the productivity of Polish farms by using the education levels on both average and marginal productivity of farms. In more recent studies, Rada et al. (2020) evaluated total factor productivity of the agriculture sector of the Russian Federation from 1994 to 2013 by decomposing it into technical progress and efficiency gains.

The findings reveal a significant positive impact of investment on infrastructure and human capital is influencing agricultural gains in South and Central districts.

\subsection{Financial development and agriculture}

323 It is well-established that financial development plays a determining role in economic growth by mobilizing savings, managing investment risks and facilitation of exchange of goods and services (Demetriades and Hussein, 1996; Greenwood and Jovanovic, 1990; Levine, 1997; Shaw, 1973). The essential role of financial sector in the agricultural sector lies in the provision of credit and finance. However, Raifu and Aminu (2019) state that commercial banks are quite guarded when it comes to lending credit to the farmers owing to high risks associated with agricultural production. Moreover, farmers, being primarily poor, are characterised by moral hazard problems where, they lack collateral to access credit. The access to credit and the facilitation of the financial sector is governed by the quality of institutions of a particular economy (Acemoglu et al., 2005). Agricultural credit boosts the development and modernization of the agricultural sector (Kohansal et al., 2008). An empirical examination of the effects of financial development in agricultural sector by Ogbanje et al. (2012), Obilor (2013), and Agunuwa et al. (2015), show positive effects on agricultural productivity. Orji et 

find similar results for Pakistan.

Anh et al. (2020)examine the relationship between agricultural credit and agricultural

GDP in Vietnam for the period of 2004-2016 and find a positive relation between the variables.

Further, Raifu and Aminu (2019) find that financial development enhances agricultural performance in Nigeria but the institutional factors like corruption, regulatory quality, government effectiveness, political stability and rule of law, impair the extent of positive credit can be attributed to the inefficient utilization of agricultural credit.

\section{Data and Methodology}

\subsection{Data description}

The present study explore the dynamic effect of climate change, renewable energy consumption, institutional quality, financial development and human capital on agricultural production, the panel data of the ASEAN-4 countries (Indonesia, Malaysia, the Philippines, and Thailand) are used over the span time of 1990 to 2016. The variables in the multivariate framework consist of agricultural production (AGP), $\mathrm{CO}_{2}$ emissions $\left(\mathrm{CO}_{2}\right)$, renewable energy consumption (REN), human capital index (HCI), quality of government (QOG), and financial development (FD). The description of the variables is given in Table 1.

Table 1. Description of the variables

\begin{tabular}{|l|l|c|}
\hline Variables & Description & Source \\
\hline Agricultural Production & $\begin{array}{l}\text { Agricultural Gross Production Index } \\
\text { Number }(2014-2016=100)\end{array}$ & FAOSTAT \\
\hline CO2 emissions & CO2 emissions (metric tons per capita) & WDI \\
\hline Human capital & Human capital index & PWT \\
\hline $\begin{array}{l}\text { Ruality of government } \\
\text { consumption }\end{array}$ & $\begin{array}{l}\text { The mean value of the ICRG variables } \\
\text { Corruption, Law and Order and } \\
\text { Bureaucracy Quality, scaled 0-1. }\end{array}$ & ICRG \\
\hline Financial development & $\begin{array}{l}\text { Renewable energy consumption(\% of total } \\
\text { final energy consumption) }\end{array}$ & WDI \\
\hline
\end{tabular}


FAOSTAT = United Nations Statistics Division of the Food and Agriculture Organization, WDI = World Development Indicators, PWT = Penn World Table, ICRG = International Country Risk Group, IMF = International Monetary Fund

To explore the potential impact of climate change, renewable energy consumption, institutional quality, financial development, and human capital on agricultural production in selected ASEAN countries, the multivariate framework is expressed as Eq. (1).

$$
A G P_{i t}=f\left(C O_{2 i t}, R E N_{i t}, H C I_{i t}, Q O G_{i t}, F D_{i t}, F D_{i t}^{2}\right)
$$

Equation 1 converted into the natural logarithm form as follows:

$$
\begin{aligned}
\operatorname{LogAGP} P_{i t}= & \alpha_{i}+\beta_{1 i} \operatorname{LogCO}_{2 i t}+\beta_{2 i} \operatorname{LogREN}_{i t}+\beta_{3 i} \operatorname{LogHCI}_{i t}+\beta_{4 i}{\log Q O G_{i t}}+\beta_{5 i} F D_{i t} \\
& +\beta_{6 i} F D_{i t}^{2}+\varepsilon_{i t}
\end{aligned}
$$

The AGP is the agricultural production followed by all independent variables included in the model. Furthermore, $\mathrm{i}=1,2,3$, and 4 represents the each panel country and $\mathrm{t}$ represents time periods.

\subsection{Cross-Section Dependence (CSD) test}

The first test required to perform for methodology selection is cross-sectional dependence test. And in this case, the studies involving panel data analysis across country, there is a possibility of the presence of common correlation and shocks among the countries. It basically arises when the countries in consideration are associated regionally or globally. In this situation, as argued by Urbain and Westerlund (2006), the hypothesis of cross-sectional independence is invalid in macroeconomic analysis where economies are strongly interrelated. This is checked by conducting the cross-sectional dependency analysis by applying the Chudik and Pesaran (2015) cross sectional dependence test.

\subsection{Panel unit root tests}


The second test is panel unit root test of stationary. As macroeconomic variables are used in our analysis, the possibility of the non-stationarity of the variables is present. Therefore, it is imperative to examine the order of integration of the variables under consideration for establishing long-run relationship among them. The conventional first-generation unit roots tests are unreliable and provides biased results with the presence of cross-sectional dependencies. Therefore, the presence of unit roots is checked by applying Cross-sectionally augmented Im, Pesaran, and Shin unit root test (CIPS), as developed by Im et al. (2003) as well as Cross-sectional augmented Dickey Fuller unit root test (CADF) by Pesaran (2007). These tests can control the effect of cross-sectional dependencies and estimate proper results. Both the CIPS and CADF tests are performed under the null hypothesis of non-stationarity of the variables against the alternative hypothesis of otherwise. The CADF unit root test statistic is computed through following expression:

$$
\Delta y_{\mathrm{it}}=a_{i}+b_{i} y_{\mathrm{i}, t-1}+c_{i} \bar{y}_{t-1}+\sum_{j=0}^{s} d_{\mathrm{ij}} \Delta \bar{y}_{t-j}+\sum_{j=1}^{s} \delta_{i j} \Delta \bar{y}_{i, t-j}+e_{\mathrm{it}}
$$

where $\bar{y}$ and $\Delta \bar{y}$ denote the cross-sectional averages of the lagged and first differences respectively. The CIPS unit root test statistic is derived from the $t$-statistic estimated from the CADF regression model, which is as follows:

$$
\mathrm{CIPS}=N^{-1} \sum_{i=1}^{N} \mathrm{CADF}_{i}
$$

It is then followed by panel cointegration analysis.

\subsection{Cointegration test}

In recent years, much consideration has recently been given to the use of co-integration techniques to measure the existence of long run relations between built-in variables, both $\mathrm{T}$ and $\mathrm{N}$, with a time-series dimension. The increasing power obtained not only for the time-series dimensions but also for the cross-sectional dimension are one of the major reasons for this 
focus. Nonetheless, several experiments do not condemn the no-cointegration null, even where theory clearly suggests co-integration. The co-integration panel approach from Westerlund (2007) examines the existence of a long-range association through CD. As a result, the researchers followed the panel approach to co-integration bootstrapping Westerlund (2007).

The co-integration bootstrap approach is more stable than traditional co-integration methods, as it relies on systemic rather than residual dynamics. The results of the Westerlund (2007) panel co-integration efficiency in decent terms relative to Pedroni (2004) are further clearly clarified in relation to Pedroni (2004). It encourages one to apply the co-integration of the Westerlund panel in long-term research.

\subsection{CS-ARDL approach}

422 In order to take into account the problem of cross-sectional dependence, in this analysis we use the cross-sectionally augmented autoregressive distributed lag (CS-ARDL) (Chudik and Pesaran, 2015). The multivariate functional form is given as:

$$
A G P_{i t}=f\left(x_{i t}, y_{i t}, y_{i t}^{2}\right)
$$
to 2016). $x_{i t}$ are the main regressor given by carbon-dioxide emission $\left(\mathrm{CO}_{2 i t}\right)$, Renewable Energy Consumption $\left(R E N_{i t}\right)$, Human Capital Index $\left(H C I_{i t}\right)$ and the Quality of Governance $\left(Q O G_{i t}\right), y_{i t}$ represent the domestic control variable given by Financial Development $\left(F D_{i t}\right)$. The effects of $\mathrm{CO}_{2 i t}, R E N_{i t}, H C I_{i t}$ and $Q O G_{i t}$ for country $i$ at time $t$ is given by the following model: 

variable heterogeneous slope coefficients, $X_{i t}$ is the vector of regressors, and $\mu_{i t}$ are the stochastic disturbances distributed independently across time and countries with $E\left(\mu_{i t}\right)=0$ and $E\left(\mu_{i t}^{2}\right)=\sigma^{2}$. Lags of order $p$ and $q$ respectively are added to the dependent and the independent variables respectively. The resulting dynamic panel ARDL (p, q) model can be written as:

443

Eq. (7) suggests that $A G P_{i t}$ is a function of the observable as well as the unobserved common factors. Hence, $\mu_{i t}$ is the composite error-term denoting a multi-factor error structure. In Eq. (8), $\omega_{i}^{\prime}$ are the factor loadings and $G_{t}$ is the vector of unobserved common factors. The sources of cross-sectional dependence of the error-terms are captured by $G_{t}$. The idiosyncratic error terms $\varepsilon_{i t}$ are assumed to be distributed independently, and uncorrelated with the regressors and the unobserved factors $\left(\mathrm{G}_{\mathrm{t}}\right) . \mathrm{G}_{\mathrm{t}}$ also affect the regressors $X_{i t}$, as shown in equation (9) where $\theta_{i}^{\prime}$ are the factor loadings, and $v_{i t}$, the idiosyncratic error components of $X_{i t}$.

In the absence of cross-sectional dependence, ARDL technique of Pesaran and Smith (1995) and Pesaran et al. (1999) produces consistent estimates of the parameters given that their order of integration is $\mathrm{I}(0)$ or $\mathrm{I}(1)$. Through an unrestricted error-correction model (ECM) as given by equation (10), the ARDL model estimates both the short- and long-run dynamics.

$$
\Delta A G P_{i t}=\propto_{i}+\xi_{i}\left(A G P_{i, t-1}-\overline{\bar{\omega}}_{i} . X_{i, t-1}\right)+\sum_{k=1}^{p-1} \emptyset_{i, k}^{*} . \Delta A G P_{i, t-k}+\sum_{k=0}^{q-1} \beta_{i, k}^{*} . \Delta X_{i, t-k}
$$


4651 and $\beta_{i, k}^{*}=\sum_{l=k+1}^{q} \beta_{i, l}$ for $\mathrm{k}=1,2, \ldots \mathrm{q}-1$. In the above equation, the long-run relationship 466 between $A G P_{i t}$ and the regressors is represented by $\left(A G P_{i, t-1}-\overline{\bar{\omega}}_{i} \cdot X_{i, t-1}\right)$. The variables

467

468

converge to long-run equilibrium if the coefficient, $\xi_{i}$ is negative and statistically significant.

The short-run dynamics are given by the coefficients $\emptyset_{i, k}^{*}$ and $\beta_{i, k}^{*}$.

The panel ARDL model was augmented to account for the problem of cross-sectional dependence by implementing the Common Correlated Effects (CCE) approach (Chudik and Pesaran, 2015). This is done by replacing the unobserved common factors in equations (7) and (8) with their cross-sectional averages. Averaging them across time we get the following:

$$
\begin{aligned}
& \overline{A G P}_{i}=\bar{\alpha}+\sum_{K=1}^{P} \bar{\emptyset}_{K} \overline{A G P_{t-k}}+\sum_{K=0}^{q} \overline{\beta_{k}^{\prime}} \bar{X}_{t-k}+\overline{\omega^{\prime}} . G_{t}+\varepsilon_{t} \\
& \text { Where, } \bar{\alpha}=\frac{\sum_{i=1}^{N} \alpha_{i}}{N}, \overline{A G P}_{t-k}=\frac{\sum_{i=1}^{N} A G P_{i, t-k}}{N}, \overline{\emptyset_{k}}=\frac{\sum_{i=1}^{N} \emptyset_{i, k}}{N} k=0,1,2 \ldots p . \\
& \bar{X}_{t-k}=\frac{\sum_{i=1}^{N} X_{i, t-k}}{N}, \overline{\beta_{k}^{\prime}}=\frac{\sum_{i=1}^{N} \beta_{i, K}^{\prime}}{N} \quad k=0,1,2, \ldots q . \\
& \overline{\omega^{\prime}}=\frac{\sum_{i=1}^{N} \omega_{i}^{\prime}}{N} \text { and } \overline{\varepsilon_{t}}=\frac{\sum_{i=1}^{N} \varepsilon_{i, t}}{N}
\end{aligned}
$$

(1)$$
\overline{\varepsilon_{t}}=0 \text { as } N \rightarrow \infty \text {. As a result, the cross-sectional dependence in } \mu_{\mathrm{it}} \text { is captured by the }
$$
linear-combination of cross-sectional averages of the dependent and independent variables as in equation (12):

$$
\overline{A G P}_{t}=\bar{\propto}+\sum_{K=1}^{P} \bar{\emptyset}_{K} A G P_{t-k}+\sum_{K=0}^{q} \bar{\beta}_{k}^{\prime} \bar{X}_{t-k}+\overline{\omega^{\prime}} \cdot G_{t}
$$

Under CS-ARDL, the panel ARDL specification of Eq. (7) becomes:

$$
\begin{aligned}
\rightarrow & \overline{\omega^{\prime}} \cdot G_{t}={\overline{A G P_{t}}}_{t} \bar{\propto}-\sum_{K=1}^{P} \bar{\emptyset}_{K} \overline{A G P_{t-k}}-\sum_{K=0}^{q} \overline{\beta_{k}^{\prime}} \bar{X}_{t-k} \\
\rightarrow G_{t} & =\frac{\left[\overline{A G P}_{t}-\bar{\propto}-\sum_{K=1}^{P} \bar{\emptyset}_{K} \overline{A G P}_{t-k}-\sum_{K=0}^{q} \bar{\beta}_{k}^{\prime} \bar{X}_{t-k}\right]}{\overline{\omega^{\prime}}}
\end{aligned}
$$$$
A G P_{i, t}=\propto_{i}+\sum_{k=1}^{p} \emptyset_{i, k} \cdot A G P_{i, t-k}+\sum_{k=0}^{q} \beta_{i, k} \cdot X_{i, t-k}+\sum_{k=0}^{S_{Z}} \rho_{i, k}^{\prime} \cdot \bar{Z}_{t-k}+\varepsilon_{i, t}
$$

where $\bar{Z}_{t}=\left(A G P_{t}, \bar{X}_{t}\right)^{\prime}$. 
491

$$
\Delta A G P_{i t}=\propto_{i}+\xi_{i}\left(A G P_{i, t-1}-\overline{\bar{\omega}}_{i} \cdot X_{i, t-1}\right)+\sum_{k=1}^{p-1} \emptyset_{i, k}^{*} . \Delta A G P_{i, t-k}+\sum_{k=0}^{q-1} \beta_{i, k}^{*} . \Delta X_{i, t-k}+
$$$$
\sum_{k=0}^{S_{Z}} \rho^{\prime}{ }_{i, k} \cdot \bar{Z}_{t-k}+\sum_{k=1}^{p-1} \xi_{k} \Delta \overline{A G P}_{t-k}+\sum_{k=0}^{q-1} \theta_{k} \cdot \Delta \bar{X}_{t-k}+\varepsilon_{i, t}
$$

494

495

where, $\Delta \overline{A G P}_{t-k}=\frac{\sum_{i=1}^{N} \Delta A G P_{i, t-k}}{N} \quad$ and $\quad \Delta \bar{X}_{t-k}=\frac{\sum_{i=1}^{N} \Delta X_{i, t-k}}{N}$

The number of cross-sectional averages included is given by $\left[T^{1 / 3}\right]$ (Chudik and Pesaran,

2015). This ensures that the residuals are cross-sectionally uncorrelated.

\section{Empirical results and discussion}

As aforementioned, cross-sectional dependency is among the most significant diagnoses to be investigated by a researcher before performing a panel data analysis. This study first starts with the estimation of cross sectional dependence test developed by Chudik and Pesaran (2015) which is present in table 2. Panel data should be subject to overall cross-sectional dependency, which allows for the correlation of all the units within the same cross-section. This is generally due to the influence of some common variables that are not observed and common to any unit, but probably in various forms. The results of cross sectional dependency indicates that null hypothesis of no cross sectional dependence is rejected at $1 \%$ level for all the 6 variables of this study. It implies that there is cross sectional dependence in the data. This also means that the variables in the sample contain cross-sectional dependence. As noted above, details on such cross-sections need to be considered before further estimates are carried out.

Table 2. Results of Chudik and Pesaran (2015) CSD test

\begin{tabular}{|l|c|c|c|}
\hline Variables & Test statistics & Variables & Test statistics \\
\hline AGP & $12.726^{\mathrm{a}}$ & CO2 & $2.667^{\mathrm{a}}$ \\
\hline FD & $12.306^{\mathrm{a}}$ & QOG & $11.631^{\mathrm{a}}$ \\
\hline REN & $12.631^{\mathrm{a}}$ & HCI & $12.720^{\mathrm{a}}$ \\
\hline a significance at 1\% level & \multicolumn{3}{|l}{} \\
\hline
\end{tabular}


513 stationary tests accounting for the cross sectional dependence. Next, we use the CIPS and

514 CADF root checks to determine the order of the model's parameters to be cross-sectional

515 dependent on the data. Hence, this study implemented two-second generation tests, which can

516 account for cross sectional dependence such as CIPS and CADF. The null hypothesis of these

517 two tests is assumed to be the Both the unit root tests demonstrate that all the core variables as

518 well as interaction variables of CO2 with HCI, QOG and REN are I(1) (see Table 3).

Table 3. Results of Second-Generation Panel Unit Root tests

\begin{tabular}{|l|c|c|c|c|c|}
\hline Variables & Level & First Diff. & Level & First Diff. & Level \\
\hline CIPS test & -1.343 & $-5.597^{\mathrm{a}}$ & QOG & -2.648 & $-4.710^{\mathrm{a}}$ \\
\hline AGP & -1.785 & $-5.104^{\mathrm{a}}$ & HCI & -1.841 & $-2.895^{\mathrm{a}}$ \\
\hline FD & -1.785 & $-5.104^{\mathrm{a}}$ & CO2*QOG & -1.366 & $-4.124^{\mathrm{a}}$ \\
\hline FD $^{2}$ & -1.897 & $-4.507^{\mathrm{a}}$ & $\mathrm{CO} 2^{*} \mathrm{HCI}$ & -0.612 & $-4.742^{\mathrm{a}}$ \\
\hline REN & -2.530 & $-5.248^{\mathrm{a}}$ & CO2*REN & -2.666 & $-4.379^{\mathrm{a}}$ \\
\hline CO2 & -2.232 & $-4.426^{\mathrm{a}}$ & QOG & 2.610 & $-4.010^{\mathrm{a}}$ \\
\hline CADF test & -1.726 & $-4.328^{\mathrm{a}}$ & HCI & -1.708 & $-3.847^{\mathrm{a}}$ \\
\hline AGP & -1.726 & $-4.328^{\mathrm{a}}$ & CO2*QOG & -1.948 & $-3.422^{\mathrm{a}}$ \\
\hline FD & -1.271 & $-4.623^{\mathrm{a}}$ & CO2*HCI & -1.536 & $-4.031^{\mathrm{a}}$ \\
\hline FD 2 & -1.658 & $-3.978^{\mathrm{a}}$ & CO2*REN & -1.521 & $-3.831^{\mathrm{a}}$ \\
\hline REN & \multicolumn{5}{|l|}{} \\
\hline CO2 & a significance at 1\% level
\end{tabular}

520

After getting the confirmation of stationarity from second generation unit root tests, we

cointegration test is performed for both the base model and augmented model. The result from

robust $\mathrm{p}$ values indicates that null hypothesis of the no cointegration can be rejected at even augmented model (see Table 4).

527

Table 4. Results of Westerlund (2007) cointegration test

\begin{tabular}{|l|c|c|c|c|}
\hline Statistics & Value & Z-value & p-value & Robust p-value \\
\hline Base Model & \multicolumn{4}{|l|}{} \\
\hline $\mathrm{Gt}$ & -3.003 & -1.582 & 0.057 & 0.000 \\
\hline $\mathrm{Ga}$ & -5.463 & 1.631 & 0.049 & 0.000 \\
\hline $\mathrm{Pt}$ & -6.842 & -2.519 & 0.006 & 0.000 \\
\hline
\end{tabular}




\begin{tabular}{|l|c|c|c|c|}
\hline $\mathrm{Pa}$ & -7.274 & 0.191 & 0.576 & 0.000 \\
\hline Augmented Model & \multicolumn{4}{|l|}{} \\
\hline $\mathrm{Gt}$ & -0.345 & 3.178 & 0.057 & 0.000 \\
\hline $\mathrm{Ga}$ & -0.127 & 2.743 & 0.043 & 0.000 \\
\hline $\mathrm{Pt}$ & 1.331 & 3.603 & 0.000 & 0.000 \\
\hline $\mathrm{Pa}$ & 0.051 & 1.687 & 0.154 & 0.000 \\
\hline
\end{tabular}

528

529

530

531

532

533

534

535

536

537

538

539

540

541

542

543

544

545

546

547

548

549

Let us now turn to the long run analysis of CS-ARDL test. The estimated results are reported in Table 5. The coefficient of $\mathrm{CO}_{2}$ emissions finds that carbon emissions negatively affect the agricultural production in the four ASEAN countries both in the long run and short run. Specifically, the result indicates that $1 \%$ increase in $\mathrm{CO}_{2}$ emissions is associated with $0.07 \%$ and $0.92 \%$ reduction in agricultural production in short run and long run respectively. This is obvious since agriculture as a sector is very climate dependent and is therefore prone to climate change (Kim and Pang, 2009). Historically, the ASEAN-4 economies are dependent heavily on fossil fuel sources where Indonesia, Malaysia and Philippines rely primarily on coal and Thailand rely on oil and gas (Marquardt, 2016). The over reliance on fossil fuel sources has contributed towards the concentration of carbon dioxide in the atmosphere for these economies and as a result the agricultural production is adversely affected. Unprecedented levels of die off of livestock have also increased in recent years due to climate disruption, adversely affecting the livestock production (Goodland, 2014).

Indeed, the fossil fuel represents the source of $90 \%$ of the $\mathrm{CO}_{2}$ which is accumulating in the atmosphere (Le Quéré et al., 2018). The large scale emission reduction in any economic sector requires renewable energy and energy efficiency and that includes the agricultural sector as well. This argument is reflected in the coefficient for the renewable energy in CS-ARDL estimation. The finding demonstrates that renewable energy has positive and significant contribution on agricultural production in the short run and long run. The seminar paper by Sandu et al. (2019) emphasized on the energy decarbonization in ASEAN economies because of the risks associated with greenhouse gas emissions which will increase significantly if not 
tackled by the development of renewable energy. The energy decarbonisation is more crucial than ever currently since the energy consumption coupled with the emissions have increased during the recent decades (Chontanawat, 2020). In the augmented model, we also wanted to see whether renewable energy development has the capability of offsetting the carbon emission and increase agricultural production for ASEAN-4 countries. The interaction between carbon emissions and renewable energy indicates a significant positive impacts on agricultural production which confirms our hypothesis.

Human capital which is associated with the formal schooling or greater understanding of technical relationship make farmers more productive and efficient (Evenson, 1988; Schultz, 1953). It is therefore important to understand the impacts of human capital on agricultural production as well. The result shows that $1 \%$ increase in human capital is associated with $1.65 \%$ and $1.42 \%$ increase in agricultural production during the short run and long run respectively. This finding falls in similar line with Djomo and Sikod (2012) for Cameroon and Lanzona (2013) for Philippines. In an analysis of Asian countries, Liu et al. (2020) found that agricultural productivity in Southeast Asian countries is determined primarily by human capital and hence investment in human capital is desirable and optimal for these economies. To see whether human capital in the form of education and technological knowledge can offset the impacts of carbon emissions on agricultural production or not, we included another interaction effect between human capital and $\mathrm{CO}_{2}$ in the augmented model. The result reveals that human capital has the capability of offsetting the $\mathrm{CO}_{2}$ emissions impacts on agricultural production.

However, the capacity of ASEAN-4 to utilize its human capital and promote R\&D activity to increase agricultural production also depends on the quality of institutions. Improvement in the quality of institutions is important for achieving sustainable development goals (Owen, 2013). In terms of corruption perception index, 3 out of the 4 countries of ASEAN-4 scored below 50, indicating that corruption is still a primary determinant whenever 
the countries wish to increase production (Schoeberlein, 2020). The result from CS-ARDL implies that if quality of institutions is improved by $1 \%$, it will result in higher agricultural production by $0.08 \%$ and $0.095 \%$ in short run and long run. Agriculture provides raw materials to the manufacturing sector and ensures food security and hence it provides a foundation for the economy and hence corruption has serious implications for the agricultural sector (Anik and Bauer, 2017). This is especially held true for the developing countries since majority of the people live in rural areas and thus voiceless because of the resource constraints (Anik and Bauer, 2017). Our result is consistent with Drebee and Abdul-Razak (2020), who found that corruption is a major determinant of agricultural sector in Iran. An interaction effect between quality of institutions and carbon emissions is also considered to see whether quality of institutions improvement can offset the effect of $\mathrm{CO}_{2}$ on agriculture. In both the short run and long run, the CS-ARDL demonstrates that if quality of institutions can be improved it will lead towards the positive development on agricultural sector by counteracting the negative impacts of carbon emissions.

Additionally, the impacts of financial development on the agricultural production has also been explored in this study. However, in contrast to the existing studies, we include financial development and its square so as to whether there exists any non-linear relationship between financial development and agricultural production. The result shows that financial development has a negative impact and its square has a positive impacts on agricultural production. This implies that relationship between financial development and agricultural production is $U$ shaped, indicating that at the initial level of financial development, agricultural production decreases but after reaching a certain threshold, the agricultural production increases substantially.

Table 5. Results of coefficient estimation for base Model

\begin{tabular}{|l|c|c|c|}
\hline & CS-ARDL & CS-DL & CCE \\
\hline Long run estimates & $-0.9237^{\mathrm{a}}$ & $-0.0786^{\mathrm{b}}$ & $-0.0178^{\mathrm{c}}$ \\
\hline CO2 &
\end{tabular}




\begin{tabular}{|l|c|c|c|}
\hline REN & $0.0493^{\mathrm{b}}$ & $0.3810^{\mathrm{b}}$ & $0.1687^{\mathrm{b}}$ \\
\hline $\mathrm{HCI}$ & $1.4271^{\mathrm{c}}$ & $4.3857^{\mathrm{b}}$ & $0.0418^{\mathrm{c}}$ \\
\hline QOG & $0.0957^{\mathrm{a}}$ & $0.2476^{\mathrm{a}}$ & $2.6225^{\mathrm{b}}$ \\
\hline FD & $-0.1196^{\mathrm{b}}$ & $-7.6817^{\mathrm{b}}$ & $-0.0911^{\mathrm{b}}$ \\
\hline FD $^{2}$ & $0.0538^{\mathrm{b}}$ & $5.0354^{\mathrm{b}}$ & $0.0660^{\mathrm{b}}$ \\
\hline \multicolumn{5}{|l|}{ Short run estimates } & - & - \\
\hline$\Delta \mathrm{CO}_{2}$ & $-0.0763^{\mathrm{b}}$ & - & - \\
\hline$\Delta \mathrm{REN}$ & $0.0578^{\mathrm{c}}$ & - & - \\
\hline$\Delta \mathrm{HCI}$ & $1.6524^{\mathrm{c}}$ & - & - \\
\hline$\Delta \mathrm{QOG}$ & $0.0812^{\mathrm{a}}$ & - & - \\
\hline$\Delta \mathrm{FD}$ & $-0.1221^{\mathrm{a}}$ & - & \\
\hline$\Delta \mathrm{FD}^{2}$ & $0.0489^{\mathrm{b}}$ & & \\
\hline a significance at 1\% level; b significance at 5\% level; c significance at 10\% level & \\
\hline
\end{tabular}

599

600

601

602

603

604

605

606

607

608

609

610

611

612

Table 6. Results of coefficient estimation for Augmented Model

\begin{tabular}{|c|c|c|c|}
\hline & CS-ARDL & CS-DL & CCE \\
\hline \multicolumn{4}{|c|}{ Long run estimates } \\
\hline $\mathrm{CO} 2 * \mathrm{QOG}$ & $0.9711^{\mathrm{a}}$ & $0.3438^{c}$ & $0.5777^{\mathrm{c}}$ \\
\hline $\mathrm{CO} 2 * \mathrm{HCI}$ & $0.5448^{\mathrm{b}}$ & $7.6836^{\mathrm{a}}$ & $0.8508^{\mathrm{a}}$ \\
\hline CO2*REN & $0.3827^{b}$ & $1.3094^{\mathrm{b}}$ & $0.3926^{\mathrm{b}}$ \\
\hline \multicolumn{4}{|c|}{ Short run estimates } \\
\hline$\triangle \mathrm{CO} 2 * \mathrm{QOG}$ & $0.2894^{\mathrm{c}}$ & - & - \\
\hline$\triangle \mathrm{CO} 2 * \mathrm{HCI}$ & $0.3783^{\mathrm{c}}$ & - & - \\
\hline$\triangle \mathrm{CO} 2 * \mathrm{REN}$ & $0.3199^{a}$ & - & - \\
\hline
\end{tabular}

\section{Conclusion and Policy recommendations}

This study utilizes the ASEAN-4 countries to investigate the relationship between climate change, renewable energy, financial development, human capital, institutional quality and agricultural production taking data from 1990 to 2016. Since these ASEAN-4 countries are closely situated, there might be possibility that a shock in one country can affect another. In this situation, it is necessary to conduct estimation techniques using second generation models. Hence, we have conducted the analysis of our variables using cross sectional augmented ARDL test or CS-ARDL test which can take into account the issue of cross sectional dependence. 
613 Further, we verified our results through other two estimating techniques such as CS-DL and

614 CCE. The findings revealed that carbon dioxide emission has a significant negative impact, renewable energy use, human capital, institutional quality have a positive impacts on agricultural production. To see whether renewable energy use, human capital and institutional quality can mitigate the effects of carbon emissions on agriculture, we have also used an augmented model where the interaction effect between carbon emissions and renewable, human capital and institutional quality is introduced. The results have confirmed that all the variables can significantly offset the carbon dioxide emissions to increase the agricultural production in ASEAN-4 countries.

The results provide us with some important policy recommendations for the agricultural sector of ASEAN-4 countries. Although many studies indicate that agriculture sector may benefit from the $\mathrm{CO}_{2}$ fertilization effect, but our results confirm that $\mathrm{CO}_{2}$ is harmful for the agricultural production in ASEAN-4. Hence, these nations must act together to control the increasing level of $\mathrm{CO}_{2}$ emissions in their economies. The use of renewable energy is extremely crucial for these economies to tackle the effect of $\mathrm{CO}_{2}$ emissions on agricultural production. The use of renewable does not only tackle the $\mathrm{CO}_{2}$ emissions, it also has direct effect on agricultural production since it can reduce the fossil fuel energy consumption of agricultural sector. In addition, education and technological innovation captured through the human capital must also be encouraged across these nations. if these countries want to mitigate the effect of climate change. Both at the high level as well as the grass root level, quality of the institutions must be improved. In ASEAN countries, credit is highly demanded, mainly for capital requirement to improve land, purchase seeds, fertilizers, breeding stocks, and machinery as well as labour payment of wages (Bashir et al., 
necessary to increase agricultural production. Hence, these nations must adopt flexible finance policies so that farmers can benefit and agricultural production can be increased. Agricultural financing can be provided by the public sector via the banks and other formal credit institutions. Thus, agricultural policies must focus on easy access to agricultural credit to increase farm productivity and improve the livelihoods of the farmers, particularly the smallholder farmers in rural economies (Elahi et al., 2018).

In the future studies, the effect of greenhouse gases along with the moderation effect of human capital, renewable energy and institutional quality can be included to see if the overall emissions affect agriculture sector in a negative way. Additionally, disaggregated analysis of renewable energy sector can also be taken since different renewable technologies may have different effects on the agriculture.

\section{Authors' contributions}

Abbas Ali Chandio performed the conception and design of the study, data collection and analysis, drafting the work, and validation of the results.

Muhammad Ibrahim Shah contributed to data collection and analysis, and results interpretation.

Narayan Sethi contributed to proofreading and final approval.

Zulqarnain Mushtaq contributed to writing the literature part, and edited the manuscript.

\section{Data availability}

The data will be available on request.

\section{Conflict of interest}

The authors declare that they have no conflict of interest.

\section{Funding}

No funding was received from conducting this study.

\section{Ethical Approval}

Not applicable

\section{Consent to Participate}

Not applicable

\section{Consent to Publish}

Not applicable 
Abbas, S., 2020. Climate change and cotton production: an empirical investigation of Pakistan. Environmental Science and Pollution Research 27, 29580-29588. Acemoglu, D., Johnson, S., Robinson, J.A., 2005. Institutions as a fundamental cause of longrun growth. Handbook of economic growth 1, 385-472. Agunuwa, E.V., Inaya, L., Proso, T., 2015. Impact of commercial banks' credit on agricultural productivity in Nigeria (time series analysis 1980-2013). International Journal of Academic Research in Business and Social Sciences 5(11), 337-350. Ahmad, K., Heng, A.C.T., 2012. Determinants of agriculture productivity growth in Pakistan. International Research Journal of Finance and Economics 95, 163-173. Ahmad, S., Tariq, M., Hussain, T., Abbas, Q., Elham, H., Haider, I., Li, X., 2020. Does Chinese FDI, Climate Change, and CO2 Emissions Stimulate Agricultural Productivity? An Empirical Evidence from Pakistan. Sustainability 12(18), 7485. Ali, S., Liu, Y., Ishaq, M., Shah, T., Ilyas, A., Din, I.U., 2017. Climate change and its impact on the yield of major food crops: Evidence from Pakistan. Foods 6(6), 39. Amin, M., Zhang, J., Yang, M., 2015. Effects of climate change on the yield and cropping area of major food crops: A case of Bangladesh. Sustainability 7(1), 898-915. Anh, N.T., Gan, C., Anh, D.L.T., 2020. Does credit boost agricultural performance? Evidence from Vietnam. International Journal of Social Economics.

687 Anik, A.R., Bauer, S., 2017. Corruption in the Agriculture Sector-Micro Level Evidence from Bangladesh, The Handbook of Business and Corruption. Emerald Publishing Limited. Anik, A.R., Breustedt, G., Bauer, S., 2011. The Impact of Corruption on Farmers' Efficiency in Rice Production: A Natural Experiment from Bangladesh. Aryal, J.P., Sapkota, T.B., Khurana, R., Khatri-Chhetri, A., Jat, M., 2019. Climate change and agriculture in South Asia: Adaptation options in smallholder production systems. Environment, Development and Sustainability, 1-31.

Bank, W., 2013. World development indicators. World Bank, Washington, DC. Retrieved from https://databank.worldbank.org/source/worlddevelopment-indicators.

Bashir, M.K., Mehmood, Y., Hassan, S., 2010. Impact of agricultural credit on productivity of wheat crop: Evidence from Lahore, Punjab, Pakistan. Pakistan Journal of Agricultural Science 47(4), 405-409. change impacts and adaptation strategies on rainfed rice production in Songkhram River Basin, 
Chandio, A.A., Jiang, Y., Rehman, A., Rauf, A., 2020a. Short and long-run impacts of climate change on agriculture: an empirical evidence from China. International Journal of Climate Change Strategies and Management.

Chandio, A.A., Jiang, Y., Wei, F., Rehman, A., Liu, D., 2017. Famers' access to credit: Does collateral matter or cash flow matter?-Evidence from Sindh, Pakistan. Cogent Economics \& Finance 5(1), 1369383.

Chandio, A.A., Magsi, H., Ozturk, I., 2020c. Examining the effects of climate change on rice production: case study of Pakistan. Environmental Science and Pollution Research 27(8), $7812-7822$.

Chiarawipa, R., SDOODEE, K.T.S., 2020. Assessing impact of weather variability and changing climate on oil-palm yield in major growing regions of southern Thailand. Journal of Agrometeorology 22(3), 274-284.

Chontanawat, J., 2020. Relationship between energy consumption, CO2 emission and economic growth in ASEAN: Cointegration and causality model. Energy Reports 6, 660-665. Chudik, A., Pesaran, M.H., 2015. Common correlated effects estimation of heterogeneous dynamic panel data models with weakly exogenous regressors. Journal of Econometrics 188(2), 393-420.

Demetriades, P.O., Hussein, K.A., 1996. Does financial development cause economic growth? Time-series evidence from 16 countries. Journal of development Economics 51(2), 387-411. Djomo, J.M.N., Sikod, F., 2012. The effects of human capital on agricultural productivity and farmer's income in Cameroon. International Business Research 5(4), 134.

Drebee, H.A., Abdul-Razak, N.A., 2020. The Impact of Corruption on Agriculture Sector in Iraq: Econometrics Approach, IOP Conference Series: Earth and Environmental Science. IOP Publishing, p. 012019.

Eckstein, D., Künzel, V., Schäfer, L., Winges, M., 2019. Global climate risk index 2020. Bonn: Germanwatch.

Elahi, E., Abid, M., Zhang, L., Ul Haq, S., Sahito, J.G.M., 2018. Agricultural advisory and financial services; farm level access, outreach and impact in a mixed cropping district of Punjab, Pakistan. Land use policy 71, 249-260.

Evenson, R.E., 1988. Human capital and agricultural productivity change.

Fami, H.S., Ghasemi, J., Malekipoor, R., Rashidi, P., Nazari, S., Mirzaee, A., 2010. Renewable energy use in smallholder farming systems: A case study in tafresh township of Iran. Sustainability 2(3), 702-716. 
Fisman, R., Svensson, J., 2007. Are corruption and taxation really harmful to growth? Firm level evidence. Journal of development economics 83(1), 63-75.

GII, 2020. Global innovative index 2020, World Intellectual Property Organization, https://www.wipo.int/edocs/pubdocs/en/wipo_pub_gii_2020.pdf.

Goodland, R., 2014. A fresh look at livestock greenhouse gas emissions and mitigation potential in Europe. Global change biology 20(7), 2042-2044.

Greenwood, J., Jovanovic, B., 1990. Financial development, growth, and the distribution of income. Journal of political Economy 98(5, Part 1), 1076-1107.

Guntukula, R., 2020. Assessing the impact of climate change on Indian agriculture: Evidence from major crop yields. Journal of Public Affairs 20(1), e2040.

Harun, S.N., Hanafiah, M.M., Aziz, N.I.H.A., 2021. An LCA-based environmental performance of rice production for developing a sustainable agri-food system in Malaysia. Environmental management 67(1), 146-161.

Hayami, Y., Ruttan, V.W., 1970. Agricultural productivity differences among countries. The American economic review 60(5), 895-911.

Hossain, M.S., Qian, L., Arshad, M., Shahid, S., Fahad, S., Akhter, J., 2019. Climate change and crop farming in Bangladesh: an analysis of economic impacts. International Journal of Climate Change Strategies and Management.

Hussain, A.H., 2012. Impact of credit disbursement, area under cultivation, fertilizer consumption and water availability on rice production in Pakistan (1988-2010).

Im, K.S., Pesaran, M.H., Shin, Y., 2003. Testing for unit roots in heterogeneous panels. Journal of econometrics 115(1), 53-74.

IPCC, 2014. “Climate change 2014”, Fifth Assessment Synthesis Report, Intergovernmental Panel on Climate Change, Geneva.

IPPC, 2014. Climate Change 2014: Synthesis Report. Geneva: Intergovernmental Panel on Climate Change, 40-54. Accessed December 2, 2017. https://www.ipcc.ch/pdf/assessmentreport/ar5/syr/AR5_SYR_FINAL_All_Topics.pdf. Iqbal, M., Ahmad, M., Abbas, K., Mustafa, K., 2003. The impact of institutional credit on agricultural production in Pakistan [with comments]. The Pakistan Development Review, 469485 .

IRENA, 2016. Renewable Energy Outlook for ASEAN, International Renewable Energy Agency, $\quad$ https://www.irena.org/publications/2016/Oct/Renewable-Energy-Outlook-forASEAN (access on 11th April, 2021). 
Janjua, P.Z., Samad, G., Khan, N., 2014. Climate change and wheat production in Pakistan: an autoregressive distributed lag approach. NJAS-Wageningen Journal of Life Sciences 68, 1319.

Jebli, M.B., Youssef, S.B., 2015. The environmental Kuznets curve, economic growth, renewable and non-renewable energy, and trade in Tunisia. Renewable and Sustainable Energy Reviews 47, 173-185.

Khan, M.K., Khan, M.I., Rehan, M., 2020. The relationship between energy consumption, economic growth and carbon dioxide emissions in Pakistan. Financial Innovation 6(1), 1-13.

Kim, M.-K., Pang, A., 2009. Climate change impact on rice yield and production risk. Journal of Rural Development/Nongchon-Gyeongje 32(1071-2016-86914), 17-29.

Kohansal, M.R., Ghorbani, M., Mansoori, H., 2008. Effect of credit accessibility of farmers on agricultural investment and investigation of policy options in Khorasan-Razavi Province. Journal of applied sciences 8.

Kotir, J.H., 2011. Climate change and variability in Sub-Saharan Africa: a review of current and future trends and impacts on agriculture and food security. Environment, Development and Sustainability 13(3), 587-605.

Lanzona Jr, L.A., 2013. Human capital and agricultural productivity: The case of the Philippines. Productivity Growth in Philippine Agriculture.

Le Quéré, C., Andrew, R.M., Friedlingstein, P., Sitch, S., Hauck, J., Pongratz, J., Pickers, P.A., Korsbakken, J.I., Peters, G.P., Canadell, J.G., 2018. Global carbon budget 2018. Earth System Science Data 10(4), 2141-2194.

Levine, R., 1997. Financial development and economic growth: views and agenda. Journal of economic literature 35(2), 688-726.

Liu, J., Wang, M., Yang, L., Rahman, S., Sriboonchitta, S., 2020. Agricultural productivity growth and its determinants in south and southeast asian countries. Sustainability 12(12), 4981. Liu, X., Zhang, S., Bae, J., 2017. The impact of renewable energy and agriculture on carbon dioxide emissions: Investigating the environmental Kuznets curve in four selected ASEAN countries. Journal of Cleaner Production 164, 1239-1247.

Mahmoud, Z.A., Ahmad, Y., Dali, M.M., Nordin, N.A., 2019. Environmental Threats to the Performance of Urban Areas in ASEAN Integration, ASEAN Post-50. Springer, pp. 177-201. Marquardt, J., 2016. How power shapes energy transitions in Southeast Asia: A complex governance challenge. Taylor \& Francis.

Masters, G., Baker, P., Flood, J., 2010. Climate change and agricultural commodities. CABI Work Pap 2, 1-38. 
802

803

804

805

806

807

808

809

810

811

812

813

814

815

816

817

818

819

820

821

822

823

824

825

826

827

828

829

830

831

832

833

834

Mendelsohn, R., 2014. The impact of climate change on agriculture in Asia. Journal of Integrative Agriculture 13(4), 660-665.

Muhammad, B., Khan, M.K., Khan, M.I., Khan, S., 2021. Impact of foreign direct investment, natural resources, renewable energy consumption, and economic growth on environmental degradation: evidence from BRICS, developing, developed and global countries. Environmental Science and Pollution Research, 1-10.

Nomman Ahmed, M., Maas, S., Schmitz, P.M., 2010. Analysing agricultural productivity growth in a framework of institutional quality.

North, D.C., 1990. Institutions, institutional change and economic performance. Cambridge university press.

Nowak, A., Kijek, T., 2016. The effect of human capital on labour productivity of farms in Poland. Studies in Agricultural Economics 118(1), 16-21.

Obilor, S.I., 2013. The impact of commercial banks' credit to agriculture on agricultural development in Nigeria: An econometric analysis. International Journal of Business, Humanities and Technology 3(1), 85-94.

Ogbanje, E., Yahaya, M., Kolawole, F., 2012. Effect of commercial banks' loan on agricultural gross domestic product (GDP) in Nigeria from 1981 to 2007. Production Agriculture and Technology Journal 8(2), 88-100.

Orji, A., Ogbuabor, J.E., Anthony-Orji, O.I., 2015. Financial liberalization and economic growth in Nigeria: An empirical evidence. International Journal of Economics and Financial Issues 5(3).

Owen, R.F., 2013. Governance and economic integration: Stakes for Asia,. Asian Development Bank Institute (ADBI) Working Paper, No. 425.

Panuju, D.R., Mizuno, K., Trisasongko, B.H., 2013. The dynamics of rice production in Indonesia 1961-2009. Journal of the Saudi Society of Agricultural Sciences 12(1), 27-37.

Pedroni, P., 2004. Panel cointegration: asymptotic and finite sample properties of pooled time series tests with an application to the PPP hypothesis. Econometric theory, 597-625.

Pesaran, M.H., 2006. Estimation and inference in large heterogeneous panels with a multifactor error structure. Econometrica 74(4), 967-1012.

Pesaran, M.H., 2007. A simple panel unit root test in the presence of cross-section dependence. Journal of applied econometrics 22(2), 265-312.

Pesaran, M.H., Shin, Y., Smith, R.P., 1999. Pooled mean group estimation of dynamic heterogeneous panels. Journal of the American statistical Association 94(446), 621-634. 
Pesaran, M.H., Smith, R., 1995. Estimating long-run relationships from dynamic heterogeneous panels. Journal of econometrics 68(1), 79-113.

Pickson, R.B., He, G., Ntiamoah, E.B., Li, C., 2020. Cereal production in the presence of climate change in China. Environmental Science and Pollution Research 27(36), 45802-45813. Praveen, B., Sharma, P., 2019. A review of literature on climate change and its impacts on agriculture productivity. Journal of Public Affairs 19(4), e1960.

Quah, J.S., 1982. Bureaucratic corruption in the ASEAN countries: a comparative analysis of their anti-corruption strategies. Journal of Southeast Asian Studies 13(1), 153-177.

Qureshi, M.I., Awan, U., Arshad, Z., Rasli, A.M., Zaman, K., Khan, F., 2016. Dynamic linkages among energy consumption, air pollution, greenhouse gas emissions and agricultural production in Pakistan: sustainable agriculture key to policy success. Natural hazards $84(1)$, 367-381.

Rada, N., Liefert, W., Liefert, O., 2020. Evaluating agricultural productivity and policy in Russia. Journal of Agricultural Economics 71(1), 96-117.

Raifu, I.A., Aminu, A., 2019. Financial development and agricultural performance in Nigeria: what role do institutions play? Agricultural Finance Review.

Rayamajhee, V., Guo, W., Bohara, A.K., 2020. The Impact of Climate Change on Rice Production in Nepal. Economics of Disasters and Climate Change, 1-24.

Rehman, A., Chandio, A.A., Hussain, I., Jingdong, L., 2017. Is credit the devil in the agriculture? The role of credit in Pakistan's agricultural sector. The Journal of Finance and Data Science 3(1-4), 38-44.

Sabir, M., Ahmed, Q.M., 2008. Economic reforms and total factor productivity growth in Pakistan: an empirical analysis. Business Review 3(1), 53-68.

Sandu, S., Yang, M., Mahlia, T.M.I., Wongsapai, W., Ong, H.C., Putra, N., Rahman, S., 2019. Energy-related $\mathrm{CO} 2$ emissions growth in ASEAN countries: Trends, drivers and policy implications. Energies 12(24), 4650.

Sarkar, M.S.K., Begum, R.A., Pereira, J.J., 2020. Impacts of climate change on oil palm production in Malaysia. Environmental Science and Pollution Research 27(9), 9760-9770.

Sarker, M.A.R., Alam, K., Gow, J., 2012. Exploring the relationship between climate change and rice yield in Bangladesh: An analysis of time series data. Agricultural Systems 112, 11-16. Schoeberlein, J., 2020. Corruption in ASEAN: Regional trends from the 2020 Global Corruption Barometer and country spotlights.

Schultz, T.W., 1953. The] economic organization of agriculture. 
Schultz, T.W., 1961. Investment in human capital. The American economic review 51(1), 117.

Schumpeter, J.A., 1982. The theory of economic development: An inquiry into profits, capital, credit, interest, and the business cycle (1912/1934). Transaction Publishers.-1982.-January 1, 244.

Shaw, E.S., 1973. Financial deepening in economic development.

SUBRAMANIAM, Y., MASRON, T.A., Subramaniam, T., 2020. Institutional quality and food security. The Singapore Economic Review, 1-29.

Takahashi, K., Barrett, C.B., 2014. The system of rice intensification and its impacts on household income and child schooling: evidence from rural Indonesia. American Journal of Agricultural Economics 96(1), 269-289.

Tirado, R., Cotter, J., 2010. Ecological farming: Drought-resistant agriculture. Exeter, UK: Greenpeace Research Laboratories.

Urbain, J.-P., Westerlund, J., 2006. Spurious regression in nonstationary panels with cross-unit cointegration. METEOR, Maastricht research school of Economics of TEchnology and ORganizations.

Verchot, L.V., Van Noordwijk, M., Kandji, S., Tomich, T., Ong, C., Albrecht, A., Mackensen, J., Bantilan, C., Anupama, K., Palm, C., 2007. Climate change: linking adaptation and mitigation through agroforestry. Mitigation and adaptation strategies for global change 12(5), 901-918.

Vermeulen, S.J., Campbell, B.M., Ingram, J.S., 2012. Climate change and food systems. Annual review of environment and resources 37, 195-222.

Warsame, A.A., Sheik-Ali, I.A., Ali, A.O., Sarkodie, S.A., 2021. Climate change and crop production nexus in Somalia: an empirical evidence from ARDL technique. Environmental Science and Pollution Research, 1-13.

WDI, 2021. World development indicators. World Bank, Washington DC.

Westerlund, J., 2007. Testing for error correction in panel data. Oxford Bulletin of Economics and statistics 69(6), 709-748.

Yuzbashkandi, S.S., Khalilian, S., 2020. On projecting climate change impacts on soybean yield in Iran: an econometric approach. Environmental Processes 7(1), 73-87.

Zaied, Y.B., Cheikh, N.B., 2015. Long-run versus short-run analysis of climate change impacts on agricultural crops. Environmental Modeling \& Assessment 20(3), 259-271.

Zakaria, M., Jun, W., Khan, M.F., 2019. Impact of financial development on agricultural productivity in South Asia. Agricultural Economics 65(5), 232-239. 
